\title{
Differences in shell size of the bivalve Varicorbula between marginal parts of the Vienna and Danube basins
}

\author{
Tomáš Fuksi \\ Slovak Academy of Science, Earth Science Institute; Dúbravská cesta 9, 84005 Bratislava, Slovakia; e-mail: geoltofu@savba.sk \\ (C) 2016 Authors. This is an open access publication, which can be used, distributed and reproduced in any medium according \\ to the Creative Commons CC-BY 4.0 License requiring that the original work has been properly cited.
}

Middle Miocene marine sediments in the Vienna and Danube Basins provide opportunities for analysis of spatial and temporal variations in the composition of molluscan communities and variations in species abundance and size. Varicorbula gibba (Olivi 1792) is an opportunistic bivalve with high tolerance to hypoxic conditions and variations in salinity (Holmes \& Miller 2006) that appears in the Oligocene and persists to present, occurring in the tropical and northern temperate Eastern Atlantic and in the Mediterranean. Varicorbula belongs to one of the most frequent species in the benthic communities in the Paratethys during the Middle Miocene. However, spatial and temporal variations in taphonomic preservation and in abundance, size, and shape of this genus is poorly known - insights into such variations would improve paleoenvironmental interpretations.

Molluscan assemblages with Varicorbula gibba (Olivi 1792) were collected from boreholes located in the western (Vienna basin) and eastern (Danube basin) margins of the Malé Karpaty Mountains (Slovakia). Boreholes intersect sediments of the Studienka Formation (Vienna Basin) respective Madunice Formation (Danube Basin) that belong mainly to the Upper Badenian stage (Janočko et al. 2003, Kováč et al. 2004). We have selected assemblages with more than 20 Varicorbula specimens from sediment samples sieved with $1 \mathrm{~mm}$ mesh size. A well preserved shelly material contains presently more than 130 specimens of Varicorbula, with ongoing screening of additional samples. We measured dimensions of four morphological variables (in $\mathrm{mm}$ ). Shell length, shell height, posterior shell length and upper shell height were measured on all specimens. The valves were photographed and the dimensions were measured using ImageJ image analysis software. We used principal component analysis (PCA) and bivariate and multivariate allometric analyses to investigate ontogenetic and spatial variations in size and shape. We find that this taxon shows significant regional-scale differences in size distribution between the coeval Upper Badenian sediments in the Vienna and Danube basins, with significantly smaller size in the Danube Basin.

In subtidal muds in the northern parts of the Vienna Basin, Varicorbula gibba achieves very high proportional community-level abundance and its median shell width ranges between 6-10 $\mathrm{mm}$. Specimens from low-energy muddy sediments of the Vienna basin show low levels of taphonomic damage but are frequently bored by naticids snails that produce the trace fossil Oichnus paraboloides (Bromley 1981, Pek et al. 1997). In contrast, muddy sands from the northeastern margin of the Danube Basin; community composition is more even and median width ranges just between 3-4 $\mathrm{mm}$. The higher sandy content and lower sedimentation rates (as evidenced by higher taphonomic damage, with higher proportion of bored specimens (by muricid snails - Oichnus simplex, in the Danube Basin; Bromley 1981) imply that the regional size differences can partly positively correlate with nutrient supply. Morphometric analyses indicate that height and width of individuals of this taxon undergo significant ontogenetic allometry and that smaller-sized individuals in the Danube Basin have a smaller width/ 
height ratio. Therefore, some shape differences in the height-width ratio between the two basins are unrelated to ontogenetic allometric effects (because height-width ratio changes even during the ontogeny).

\section{REFERENCES}

Bromley R.G., 1981. Concepts in ichnotaxonomy illustrated by small round holes in shells. Acta Geologica Hispanica, 16, 55-64.
Holmes S.P. \& Miller N., 2006. Aspects of the ecology and population genetics of the bivalve Corbula gibba. Marine Ecology Progress Series, 315, 129-140.

Janočko J., Elečko M., Karoli S., Konečný V., Kováč M., Nagy A., Vass D., Jacko S. \& Kaličiak M., 2003. Sedimentary evolution of the Tertiary basins of the Western Carpathian. Mineralia Slovaca, 35, 3-4, 211-254.

Kováč M., Baráth I., Harzhauser M., Hlavatý I. \& Hudáčková N., 2004. Miocene depositional systems and sequence stratigraphy of the Vienna Basin. Courier For schungsinstitut Senckenberg, 246, 187-212.

Pek I., Mikuláš R. \& Lysáková G., 1997. Boring ichnofossils on Mollusc Shells from the late Badenian at Rohožník. Zemní plyn a nafta, 42, 47-52. 